\section{Efficacy and pharmacokinetics of erector spinae plane block in children}

\section{To the Editor}

I read with great interest the recently published study by Macaire $e t ~ a l^{1}$ on bilateral erector spinae plane block (ESPB). It is apparent that the authors have put substantial effort into their study. However, in line with the Editorial in the same issue, ${ }^{2}$ partly dealing with issues related to the peer-review process, I would like to raise two issues that need further comment:

First, in the first paragraph of the Discussion, it is suggested that bilateral ESPB with intermittent bolus injections is a useful technique in the context of pediatric cardiac surgery. However, the design of the study, where both groups initially were treated with bilateral ESPB, together with the lack of the two all-important control groups outlined in our recent Daring Discourse, ${ }^{3}$ make the interpretation of the results quite complex and non-conclusive. What can be concluded is that repeated administration of parenteral local anesthetics does reduce opioid requirements and vomiting, something that is already described in the literature. ${ }^{4}$

Second, the pharmacokinetic part of the study is intriguing. There is no explanation why the plasma levels were only studied in 10 out of the 27 patients receiving repeated boluses of ropivacaine. Were these patients the first 10 consecutive cases or were there some sort of randomization? Or were they the last 10 , realizing that analyzing plasma levels were a necessary part of the study? Furthermore, the authors report the 48 hours results as mean \pm SD $(0.46 \pm 0.49$ $\mu \mathrm{g} \mathrm{mL}-1)$. This represents a textbook example of a non-Gaussian distribution since the SD is larger than the mean value.
Since the plasma level for obvious reasons cannot be a negative value, this implies that some of the 1048 hours samples may have been deviating considerably from the mean value, being quite high. I look forward to the presentation of the individual values in the authors' response to this letter. Additionally, the analysis methodology for ropivacaine is just described as gas chromatography with an upper detection limit of 5 microgram/ $\mathrm{mL}-1$, accompanied by a reference for more detail. When you look up this citation, that publication (by some of the same authors) in fact analyzes levo-bupivacaine. However, there is in turn an additional reference regarding ropivacaine, but this reference is describing liquid chromatography-electrospray mass spectrometry determination of ropivacaine, ${ }^{5}$ something that is very different from gas chromatography. Not only is the most adequate analysis method not gas chromatography, but it must also be considered that you need to do your calculations in relation to the fact that ropivacaine in this setting is the ropivacaine base with a relative molar mass of $274^{6}$ and not on the ropivacaine molecule itself. In summary, to analyze ropivacaine properly is a demanding endeavor. Thus, against the above I unfortunately find the pharmacokinetic data reported by the authors highly questionable.

\section{Per-Arne Lonnqvist $\odot$}

Department of Physiology \& Pharmacology, Karolinska Institute, Stockholm, Sweden

Correspondence to Dr Per-Arne Lonnqvist, Physiology \& Pharmacology, Karolinska Institute, Stockholm, Stockholm, Sweden;

Per-Arne.Lonnqvist@ki.se

Contributors I am the sole author of this letter.

Funding The authors have not declared a specific grant for this research from any funding agency in the public, commercial or not-for-profit sectors.

Competing interests None declared.

Patient consent for publication Not required.

Provenance and peer review Not commissioned; internally peer reviewed.

\section{(2) OPEN ACCESS}

Open access This is an open access article distributed in accordance with the Creative Commons Attribution Non Commercial (CC BY-NC 4.0) license, which permits others to distribute, remix, adapt, build upon this work non-commercially, and license their derivative works on different terms, provided the original work is properly cited, an indication of whether changes were made, and the use is non-commercial. See: http:// creativecommons.org/licenses/by-nc/4.0/.

(C) American Society of Regional Anesthesia \& Pain Medicine 2021. Re-use permitted under CC BY-NC. No commercial re-use. Published by BMJ. 
To cite Lonnqvist P-A. Reg Anesth Pain Med 2021;46:1013-1014.

Received 1 December 2020

Accepted 4 December 2020

Published Online First 25 January 2021

\section{CLinked}

- http://dx.doi.org/10.1136/rapm-2020-102459

Reg Anesth Pain Med 2021;46:1013-1014. doi:10.1136/rapm-2020-102354

\section{ORCID iD}

Per-Arne Lonnqvist http://orcid.org/0000-0002-85861429

\section{REFERENCES}

1 Macaire P, Ho N, Nguyen V, et al. Bilateral ultrasoundguided thoracic erector spinae plane blocks using a programmed intermittent bolus improve opioid-sparing postoperative analgesia in pediatric patients after open cardiac surgery: a randomized, double-blind, placebocontrolled trial. Reg Anesth Pain Med 2020;45:805-12.

2 Sites BD, Brummett CM, Buvanendran A, et al. Editors' commentary. Reg Anesth Pain Med 2020;45:755-6.

3 Lonnqvist PA, Karmakar MK, Richardson J, et al. Daring discourse: should the ESP block be renamed RIP II block? Reg Anesth Pain Med 2021;46:57-60.

4 Beaussier M, Delbos A, Maurice-Szamburski A, et al. Perioperative use of intravenous lidocaine. Drugs 2018;78:1229-46.

5 Mathieu O, Hillaire-Buys D, Dadure C, et al. Liquid chromatography-electrospray mass spectrometry determination of free and total concentrations of ropivacaine in human plasma. J Chromatogr B Analyt Technol Biomed Life Sci 2006;831:91-8.

6 Lönnqvist PA, Westrin P, Larsson BA, et al. Ropivacaine pharmacokinetics after caudal block in 1-8 year old children. Br J Anaesth 2000;85:506-11. 